ORIGINAL ARTICLE

\title{
Evaluation of phenolic and antioxidant properties of strawberry as a function of extraction conditions
}

\author{
Avaliação de fenólicos e atividade antioxidante em morango \\ em função das condições de extração
}

\author{
Raquel de Pinho Ferreira Guiné ${ }^{1 *}$ (1), Paula Maria dos Reis Correia ${ }^{1}$ (D), \\ Ana Cristina Ferrão ${ }^{1}$, Fernando Gonçalves ${ }^{1}$ (D), Clémence Lerat ${ }^{2,3}$, \\ Theo El-Idrissi ${ }^{2,3}$, Eva Rodrigo ${ }^{2,4}$
}

${ }^{1}$ Instituto Politécnico de Viseu (IPV), Escola Superior Agrária de Viseu, Centro de Recursos Naturais, Ambiente e Sociedade (CERNAS), Departamento de Indústrias Alimentares, Ranhados, Viseu, Portugal

${ }^{2}$ Instituto Politécnico de Viseu, Departamento de Indústrias Alimentares, Ranhados, Viseu, Portugal

${ }^{3}$ Université Angers Angers, Institut Universitaire de Technologie, Angers, France

${ }^{4}$ Universidad de Granada, Departamento de Biología, Facultad de Ciencias, Granada, España

*Corresponding Author: Raquel de Pinho Ferreira Guiné, Instituto Politécnico de Viseu (IPV), Centro de Recursos Naturais, Ambiente e Sociedade (CERNAS), Departamento de Indústrias Alimentares, Quinta da Alagoa, Estrada de Nelas, 3500-606, Ranhados/Viseu - Portugal, e-mail: raquelguine@esav.ipv.pt

Cite as: Guiné, R. P. F., Correia, P. M. R., Ferrão, A. C., Gonçalves, F., Lerat, C., El-Idrissi, T., \& Rodrigo, E.

(2020). Evaluation of phenolic and antioxidant properties of strawberry as a function of extraction conditions.

Brazilian Journal of Food Technology, 23, e2019142. https://doi.org/10.1590/1981-6723.14219

\begin{abstract}
We studied the extraction of antioxidant phenolic compounds, anthocyanins and the evaluation of antioxidant activity of strawberries in different extraction conditions, varying the type of solvent (ethanol:water $(50 \%)$ and acetone:water (60\%), the extraction time (15 and $60 \mathrm{~min})$ and the solvent volume to sample mass ratio $(5 \mathrm{~mL} / \mathrm{g}$ and $20 \mathrm{~mL} / \mathrm{g}$ ). In addition, we performed principal component analysis and cluster analysis. The results showed that, although the two solvents tested had similar influence on total phenolic compounds extraction and antioxidant activity, the 60 minutes of extraction and the use of the solvent volume/sample mass ratio of $20 \mathrm{~mL} / \mathrm{g}$ were the best extraction conditions, both for the $1^{\text {st }}$ and $2^{\text {nd }}$ recovered extracts. However, the solvent had a marked effect on anthocyanins' extraction, so that acetone/water extracted almost the double as compared to ethanol/water, for the same extraction conditions. Finally, factor analysis allowed identifying a grouping structure of two components, which was confirmed by the dendogram obtained from cluster analysis.
\end{abstract}

Keywords: Phenolic compounds; Anthocyanins; Antioxidant activity; Cluster analysis; Factor analysis; Fragaria ananassa.

\section{Resumo}

A extração de compostos fenólicos e antocianinas, e a avaliação da atividade antioxidante de morangos em diferentes condições de extração foram estudadas, variando o tipo de solvente, o tempo de extração e a razão entre o volume de solvente e a massa de amostra. Adicionalmente, uma análise de componentes principais e uma análise de agrupamento foram realizadas. Os resultados mostraram que, embora os dois solventes testados tenham 
influência semelhante na extração de compostos fenólicos totais e na atividade antioxidante, os 60 minutos de extração e a relação volume de solvente/massa de amostra de $20 \mathrm{~mL} / \mathrm{g}$ mostraram ser as melhores condições de extração, quer para o primeiro como para o segundo extrato recuperado. No entanto, o solvente teve um efeito marcante sobre a extração de antocianinas, de modo que a acetona/água extraiu quase o dobro em comparação com o etanol/água, para as mesmas condições de extração. Finalmente, a análise fatorial permitiu identificar uma estrutura de agrupamento de dois componentes, o que foi confirmado pelo dendograma obtido a partir da análise de agrupamento.

Palavras-chave: Compostos fenólicos; Antocianinas; Atividade antioxidante; Análise de clusters; Análise fatorial; Fragaria ananassa.

\section{Introduction}

Fruits and vegetables present in human diet play an important role in promoting health, due to their high number of bioactive compounds as well as other macro and micro nutrients (Arend et al., 2017; Guiné et al., 2018a; Mazzoni et al., 2017). Among the benefits associated with the consumption of fruits and vegetables are the high antioxidant activity that protects cells allied to a reduced risk of cardiovascular diseases, neurodegenerative disorders and cancer (Andrade et al., 2017; Guiné et al., 2019; Méndez-Lagunas et al., 2017). Several evidences suggest that these health benefits are related to the presence of phytochemicals, such as phenolic compounds (Ferreira et al., 2017). Phenolic compounds are secondary metabolites present in plants with an important role in the sensory and nutritional quality of fruits, vegetables and other plants (Guiné et al., 2015a, 2018c; Zhang et al., 2019a). They have also been identified as the major antioxidants in fruits (Zhang et al., 2019b).

Strawberries (Fragaria ananassa) are among the most widely consumed berries in the world. They are a rich source of antioxidant compounds including vitamins $\mathrm{C}, \mathrm{E}, \beta$-carotene, melatonin, phenolic compounds and anthocyanins as well as bioactive sugars (Álvarez-Fernández et al., 2014; Guerrero-Chavez et al., 2015; Rodríguez-Gutiérrez et al., 2019; Stürtz et al., 2011). In a study that analyzed the antioxidant activity in 12 fruits, strawberries showed the highest antioxidant activity when compared to other fruits and, in addition, the contribution of vitamin $\mathrm{C}$ to the total antioxidant activity was estimated as being less than $15 \%$ (Maraei \& Elsawy, 2017). The phenolic compounds present in strawberries influence their quality, contributing to sensorial and organoleptic attributes, as well as to health properties (Álvarez-Fernández et al., 2014; Morales-Quintana \& Ramos, 2019). The major phenolic compounds in strawberries are anthocyanins, flavan-3-ols, ellagitannins, glycosides of quercetin and kaempferol (Aaby et al., 2012). Among those bioactive compounds, quercetin is the one with highest antioxidant activity (Méndez-Lagunas et al., 2017).

Genetics, environmental elements, ripeness state and storage conditions are known to affect strawberries' quality (Yang et al., 2016; Tulipani et al., 2011). The phenolic and anthocyanin content are dependent on the cultivar, place of cultivation and time of year (Arend et al., 2017). Furthermore, in order to keep optimal quality during storage and handling it is essential that the harvesting is carried out at the appropriate maturity stage and the storage conditions are controlled (Bose et al., 2019). Aaby et al. (2012) found that the content of all phenolic compounds was affected by cultivar, but the anthocyanin profile was very similar of berries of a cultivar, being slightly influenced by ripening or growing conditions.

Extraction is the first step for plant's phenolic compounds study, which plays a significant and crucial role on the obtained results and outcomes (Azmir et al., 2013). There are different techniques for the extraction of phenolic compounds and in all of them it is essential to select the ideal conditions in order to obtain the best results, which also depend on the type of food that is being analyzed (Azmir et al., 2013; Guiné et al., 2015b). Independently of the technique used, the aims are to extract the bioactive compounds from complex plant sample, increase selectivity of the methods and concentration of target groups, and convert the bioactive compounds in suitable forms for detection and separation, leading to a strong and reproductive method. 
Presently many methodologies can be used to extract phenolics, such as maceration, infusion, digestion, decoction, percolation, Soxhlet extraction, aqueous alcoholic extraction by fermentation, countercurrent extraction, ultrasound extraction, supercritical fluid extraction and phytonics processes (Manousi et al., 2019). Among the techniques used to recover antioxidant phenolic compounds, the solid-liquid extraction has been widely employed to isolate different compounds (Ballesteros et al., 2014). This technique was designed to separate the soluble phenolic compounds by diffusion from a plant material using a solvent (liquid). Moreover, several parameters can affect the efficiency of the extraction process, namely the type and the concentration of the solvent, solvent/solid ratio, time of the extraction and temperature (Ballesteros et al., 2014). Many solvents can be used for the extraction of phenolic compounds, such as methanol, ethanol, acetone, water or their mixtures with water (Chanioti \& Tzia, 2018; Manousi et al., 2019). The recovery of the phenolic compounds depends on the type of solvent used, its polarity and the solubility of phenolic compounds in the extraction solvent. Molecular affinity between solvent and solute, mass transfer, use of co-solvent, environmental safety, human toxicity and financial feasibility should also be considered for selection of a solvent for bioactive compound extraction. In addition, in the last years a concern has been devoted to the selection of environmental friendly techniques and solvents (Azmir et al., 2013; Silva et al., 2017). Mokrani \& Madani (2016) mention that the polarities of phenolic compounds greatly vary, and it is hard to develop a single method for efficient extraction of all phenolic compounds. Furthermore, the extraction time can vary from $1 \mathrm{~min}$ to $24 \mathrm{~h}$, and longer extraction times may increase phenolic compounds' oxidation (Naczk \& Shahidi, 2004).

This study aimed to evaluate the effect of different extraction conditions on the amount of phenolic compounds and anthocyanins as well as antioxidant activity in strawberries, and complement the analysis with statistical data analysis, using principal component and cluster analysis to identify patterns of similarity between the samples studied.

\section{Material and methods}

\subsection{Samples and extraction methodology}

The strawberries (Fragaria ananassa) used for analysis were obtained in May from the local market, in a maturation state ready for consumption. In the laboratory they were grounded, after washing and removal of the leaves, to obtain a uniform mass of pulp. Different experimental conditions were tested in each essay, such as variation of extraction solvent (ethanol:water (50:50, v:v) and acetone:water (60:40, v:v)), variation of extraction time (15 and $60 \mathrm{~min}$ ), variation of the solvent volume/sample mass ratio (VMR) $(5 \mathrm{~mL} / \mathrm{g}$ and $20 \mathrm{~mL} / \mathrm{g})$, temperature 10 to $20^{\circ} \mathrm{C}$. The extracts obtained $\left(1^{\text {st }}\right.$ and $\left.2^{\text {nd }}\right)$ in each of the essays were later used to evaluate the phenolic composition and the antioxidant activity. For the extraction of the phenolic compounds, we used samples of $5 \mathrm{~g}$ from the grounded fruit. For each sample, we carried out two successive extraction steps. The first extraction allowed obtaining extract named " 1 st"and then the solvent was removed though filtration and the same mass of sample was submitted to the second successive extraction, thus allowing to obtain extract named " 2 nd".

\subsection{Quantification of total phenolic compounds}

The quantification of the total phenolic compounds (TPC) in the different extracts was adapted from the Folin-Ciocalteu method as referred by Gonçalves et al. (2012) and Guiné et al. (2014). The absorbance was measured by spectrophotometry at $760 \mathrm{~nm}$ and a calibration curve was prepared with standard solutions of gallic acid. The results were expressed as a mean of three repetitions and the units were milligrams of gallic acid equivalents (GAE) per gram of fresh sample. 


\subsection{Quantification of anthocyanins}

The total anthocyanins (ANT) were quantified using the $\mathrm{SO}_{2}$ bleaching method (Guiné et al., 2018b). The absorbance was measured at $520 \mathrm{~nm}$ and in this case, the calibration curve was prepared with standard solutions of malvidin-3-o-glicoside. The results were expressed as a mean of three repetitions and the units were micrograms of malvidin equivalents $(\mathrm{Mv} 3 \mathrm{G})$ per gram of fresh sample.

\subsection{Evaluation of antioxidant activity}

We determined the antioxidant activity (AOA) using the free radical 2,2'-azino-bis(3-ethylbenzthiazoline6-sulphonic acid (ABTS), following procedures described in Guiné et al. (2014) and Santos et al. (2014). The absorbance was measured at $734 \mathrm{~nm}$ to assess the percentage of inhibition, using a calibration curve previously obtained using different solutions of Trolox. The results were expressed as a mean of three repetitions and the units were micromoles of Trolox equivalents (TE) per gram of fresh sample.

\subsection{Statistical analysis}

The data obtained were subjected to statistical analysis using software SPSS from IBM (Version 24), establishing a level of significance of 5\%. Principal component analysis and hierarchical cluster analysis were also performed using the software mentioned.

\section{Results and discussion}

\subsection{Total phenolic compounds}

The type of solvent, the solvent/solid ratio, and the extraction time are important factors in extraction processes, due to their effects on phenolic compounds' release and antioxidant activity of the extracts.

Figure 1 shows the total phenolic compounds (TPC) in strawberries. The encountered contents of TPC are consistent with those reported for several varieties and genotypes of fresh strawberries (Méndez-Lagunas et al., 2017; Yildiz et al., 2014). This indicates that the design of the experimental conditions was well established, mainly the choice of the solvents, the extraction times and the volume/ mass ratio.
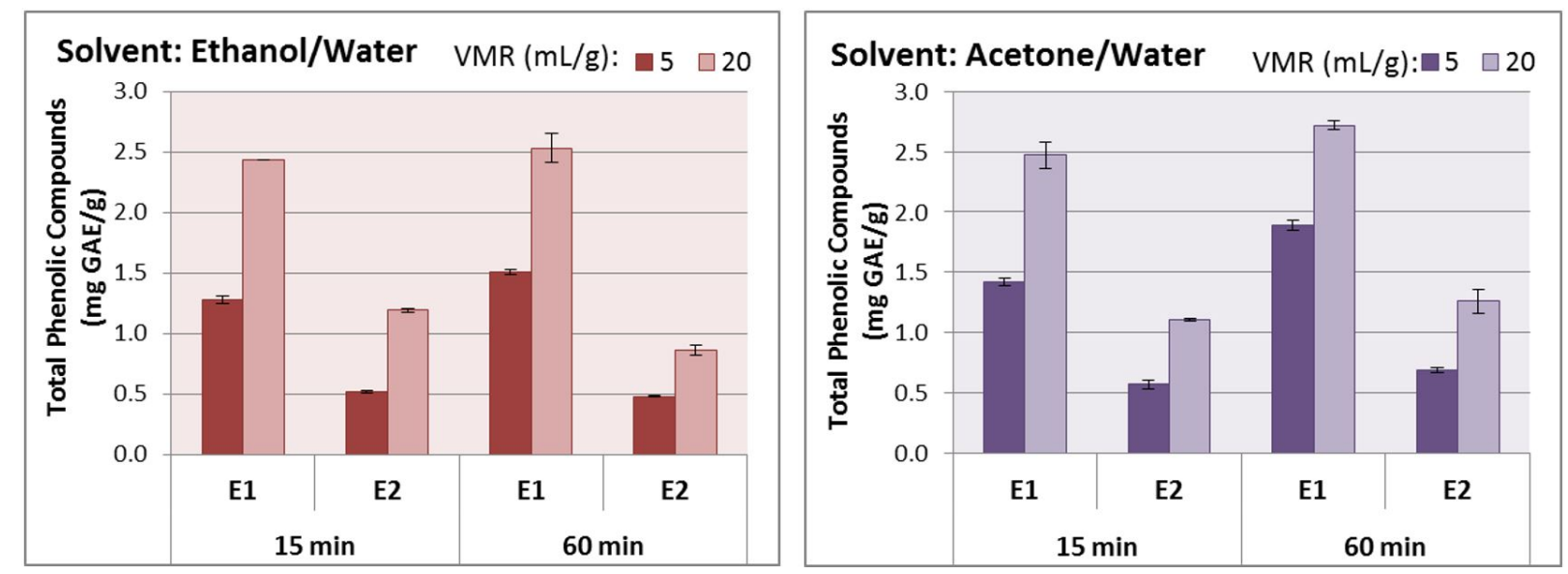

Figure 1. Total phenolic compounds evaluated in the different extracts $\left(E 1=1^{\text {st }}\right.$ extract, $E 2=2^{\text {nd }}$ extract $)$, considering two extractions times, two solvent combinations and two values of VMR (VMR = volume/mass ratio). 
The results show that some of the operational variables exerted a market effect on the TPC extraction. The $1^{\text {st }}$ extract presented more than double of the content when compared to the second fraction in both tested solvent combinations. This was also observed when the VMR increased from 5 to $20 \mathrm{~mL} / \mathrm{g}$. Moreover, when the VMR was $20 \mathrm{~mL} / \mathrm{g}$ there was a great increase in the TPC. The type of solvent solution used also influenced the TPC, being higher for acetone/ water solvent and 60 minutes of extraction. Thus, the best experimental conditions for total phenolic compounds extraction were a VMR of $20 \mathrm{~mL} / \mathrm{g}$, for 60 minutes, both for ethanol and acetone water mixtures. These results confirm the importance of establishing the extraction conditions to maximize the extraction of TCP.

\subsection{Anthocyanins}

Anthocyanins are the most important subcategory of flavonoids, which are water-soluble glycosides of anthocyanidins (Craft et al., 2012). The anthocyanins of strawberries are responsible for the berries' bright red color, and they are the group of phenolic compounds, which historically has received most attention.

The acetone/water solvent was more efficient in the anthocyanins' extraction (Figure 2b), either for the $1^{\text {st }}$ or $2^{\text {nd }}$ extracts. We observed that the variation of the solvent volume/sample mass ratio enhanced the content of the anthocyanins in the extracts when the used solvent was ethanol/water (Figure 2a), but for the $2^{\text {nd }}$ extracts with acetone/water (Figure $2 b$ ) there was an opposite tendency when the VMR increased. Generally, the increasing of the extraction time also increased the content of anthocyanins.

(a)

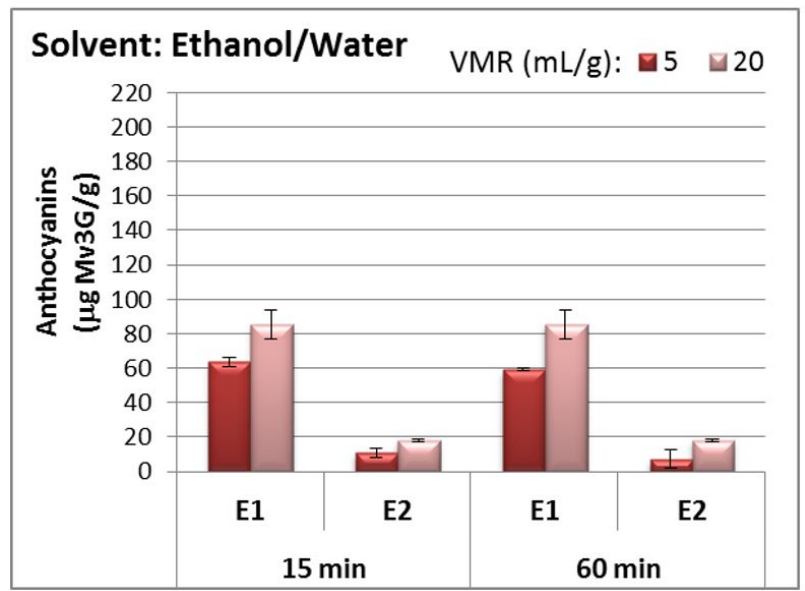

(b)

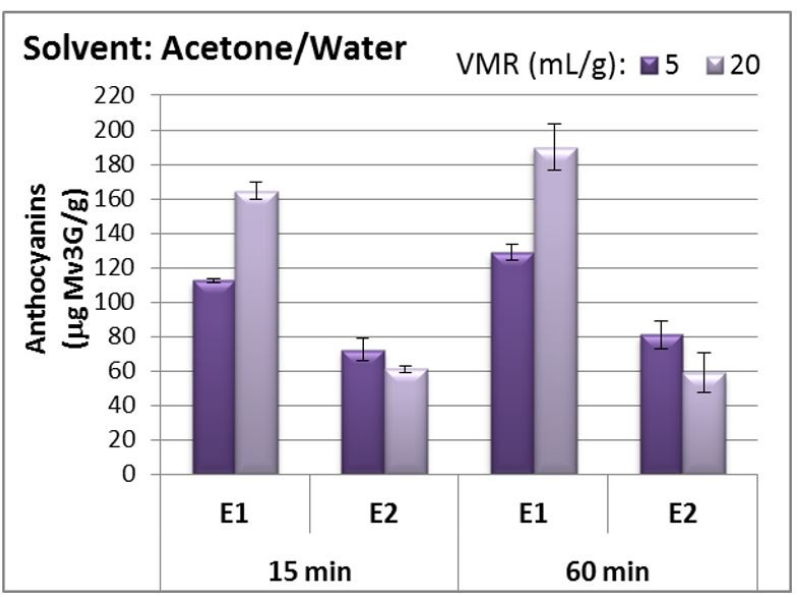

Figure 2. Anthocyanins evaluated in the different extracts $\left(E 1=1^{\text {st }}\right.$ extract, $E 2=2^{\text {nd }}$ extract $)$, considering two extractions times, two solvent combinations and two values of VMR (VMR $=$ volume/mass ratio).

Several authors also mentioned that acetone presented good extraction yields of anthocyanins from different plant sources, like mashua tubers (Chirinos et al., 2007), chia seeds (Alcântara et al., 2019), mustard grains (Rasera et al., 2019) and specifically from strawberries (Kajdžanoska et al., 2011). It is important to mention that water in combination with other solvents, as acetone, contributes to the creation of a moderate polar medium that ensures the extraction of polyphenols (Lapornik et al., 2005). In fact, Dent et al. (2013) found that the binary solvent systems are more efficient than mono-solvent ones in the extraction of phenolic compounds regarding their polarity. 


\subsection{Antioxidant activity}

Figure 3 shows the high antioxidant activity with similar results for both solvents used: ethanol/water (Figure 3a) and acetone/water (Figure 3b). The observed antioxidant activity showed similar values as other strawberry fruits (Oszmiański \& Wojdyło, 2009; Shin et al., 2008), as well as other fruits, like apple, peach or kiwi (Stratil et al., 2007). The high levels of antioxidant activity are associated with the content of phenolic compounds as demonstrated by our results.

(a)

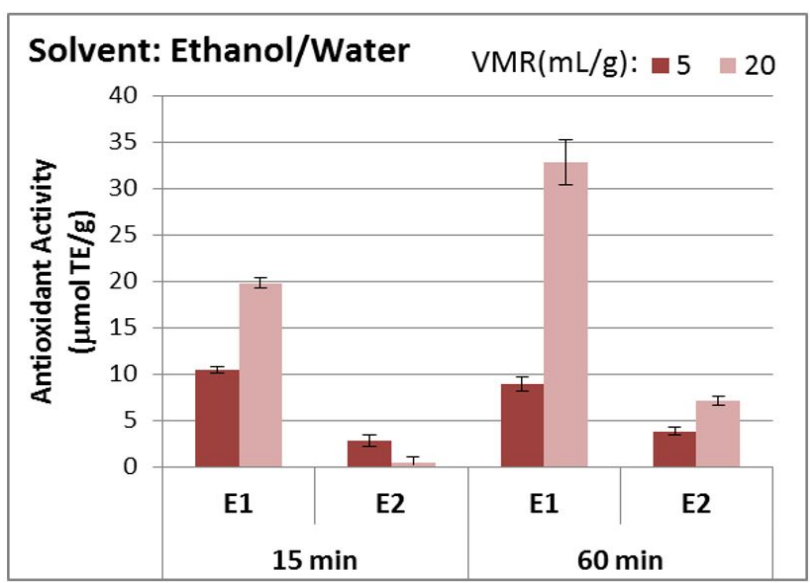

(b)

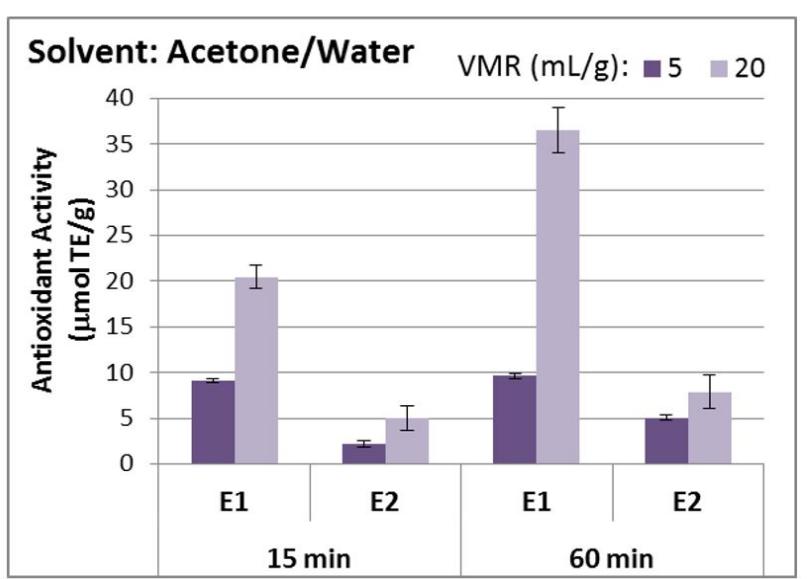

Figure 3. Antioxidant activity evaluated in the different extracts $\left(E 1=1^{\text {st }}\right.$ extract, $E 2=2^{\text {nd }}$ extract $)$, considering two extractions times, two solvent combinations and two values of VMR (VMR = volume/mass ratio).

Generally, the longer extraction time and higher VMR increased the antioxidant activity, and the $1^{\text {st }}$ extracts presented the highest contents. However, in the $2^{\text {nd }}$ extract, when extraction time increased from 15 minutes to 60 minutes, the antioxidant activity diminished considerably. The different solvents did not influence the antioxidant activity. Moreover, Mussatto et al. (2011) also found that the solvent/ solid ratio and extraction time affected the antioxidant activity of the spent coffee grounds extracts. The results showed that the content of total phenolic compounds, anthocyanins and antioxidant activity were positively correlated (Table 1). Other researchers (Ballesteros et al., 2014; Craft et al., 2012; Mokrani \& Madani, 2016) also corroborated these tendencies.

Nowadays, there is a growing interest in environmentally acceptable and efficient extraction methods. Thus, the processes that use low solvent consumption, short extraction time (economizing energy and cost of extraction), high extraction yield, environmental and food safety are the ones preferred (Azmir et al., 2013; Dent et al., 2013). Ours results show that all these requirements were achieved with the best-encountered extraction conditions tested.

\subsection{Principal Component Analysis (PCA) and Cluster Analysis (CA)}

The TPC, ANT and AOA properties of the different samples were simultaneously analyzed using principal component Analysis (PCA). For that, the data was tested to verify appropriateness for the application of PCA. From the analysis of the correlation matrix, it was found that all values were higher than 0.7 , thus being very appropriate for this type of data treatment. The highest correlation was 0.887, between ANT and TPC, followed by 0.764 for AOA versus TPC and finally 0.704 for AOA versus ANT. In addition, the results of the Bartlett's test indicated the adequacy of data, since the $\mathrm{p}$-value was highly significant $(p<0.0005)$, thus leading to the rejection of the null hypothesis that the correlation matrix was equal to the identity matrix (Broen et al., 2015). 
For sampling adequacy, the KMO (Kaiser-Meyer-Olkin) value was equal to 0.708 , being considered average according to the classification of Kaiser \& Rice (1974). Hence it is confirmed the suitability of the data for the application of the PCA technique. The analysis of the anti-image correlation matrix showed that there wasn't any MSA (Measure of Sampling Adequacy) lower than 0.5, meaning that all the variables were proper for inclusion in the analysis (MSA for $\mathrm{TPC}=0.642$, for $\mathrm{ANT}=0.685$ and for $\mathrm{AOA}=0.850$ )

The solution obtained by PCA retained 2 components, PC1 and PC2, related to the variables at study according to the results shown in Table 1. PC1 explained more than $98 \%$ of total variance in the data, and considering both components (PC1 and $\mathrm{PC} 2$ ) the variance explained was $99.997 \%$, which is adequate.

Table 1. Component matrix with loading factors for each component.

\begin{tabular}{ccccc}
\hline \multirow{2}{*}{ Components } & \multicolumn{3}{c}{ Variables } & $\begin{array}{c}\text { \% variation } \\
\text { explained }\end{array}$ \\
\cline { 2 - 5 } & TPC & ANT & AOA & $\mathbf{9 8 . 0 5 0 \%}$ \\
\hline PC1 & 0.774 & 0.718 & -000 & $\mathbf{1 . 9 4 7 \%}$ \\
\hline PC2 & 0.477 & 0.696 & - & $\mathbf{2 5 0}$ \\
\hline
\end{tabular}

We identified agglomeration in the representation of component scores (PC1 and PC2) for each sample (Figure 4), indicated in the graph as group 1 (G1) and group 2 (G2).

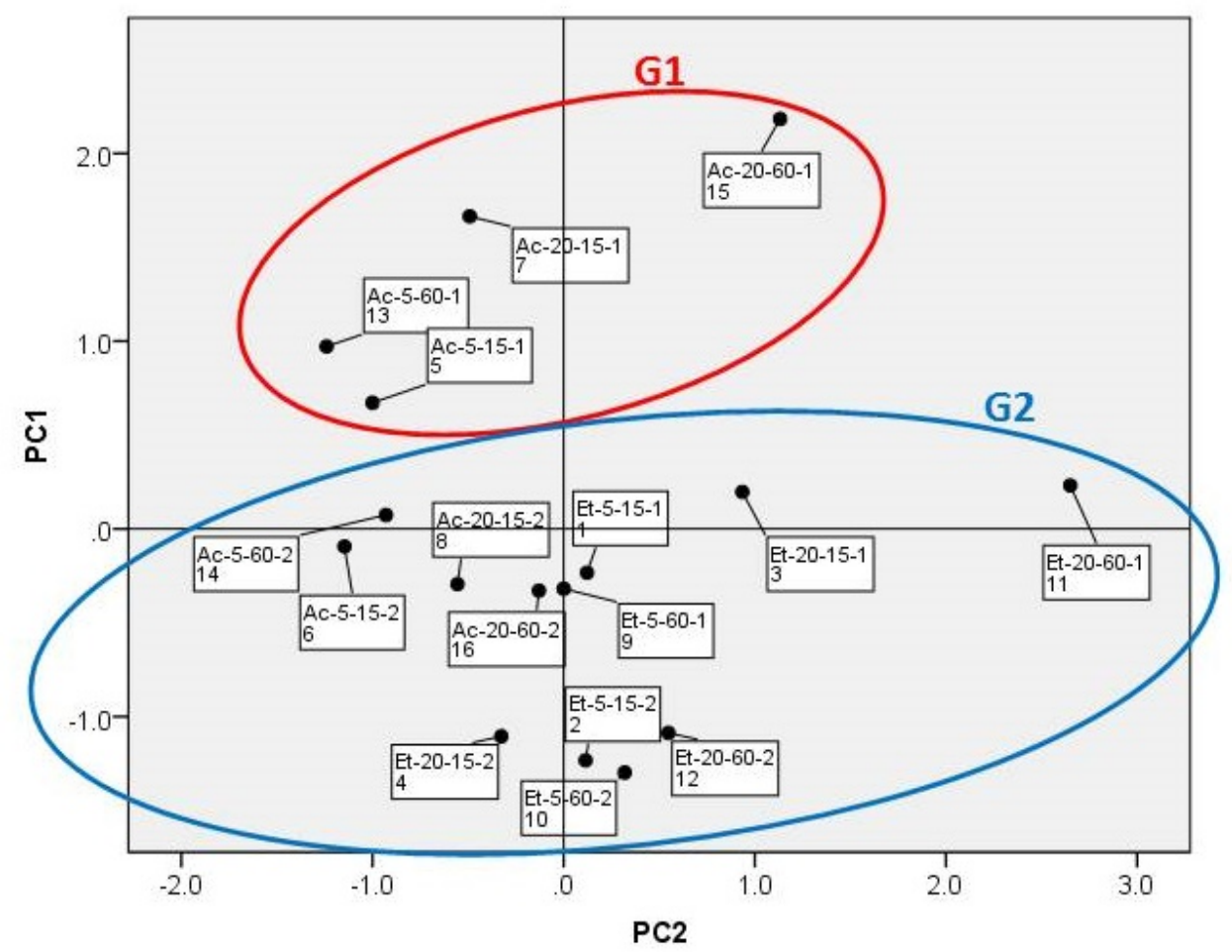

Figure 4. Principal component map determined by principal components 1 (PC1) and 2 (PC2) of the different samples analyzed as to total phenolic, anthocyanins and antioxidant activity.

This grouping structure was confirmed by the dendogram obtained from cluster analysis with WARD method of calculation, presented in Figure 5. 


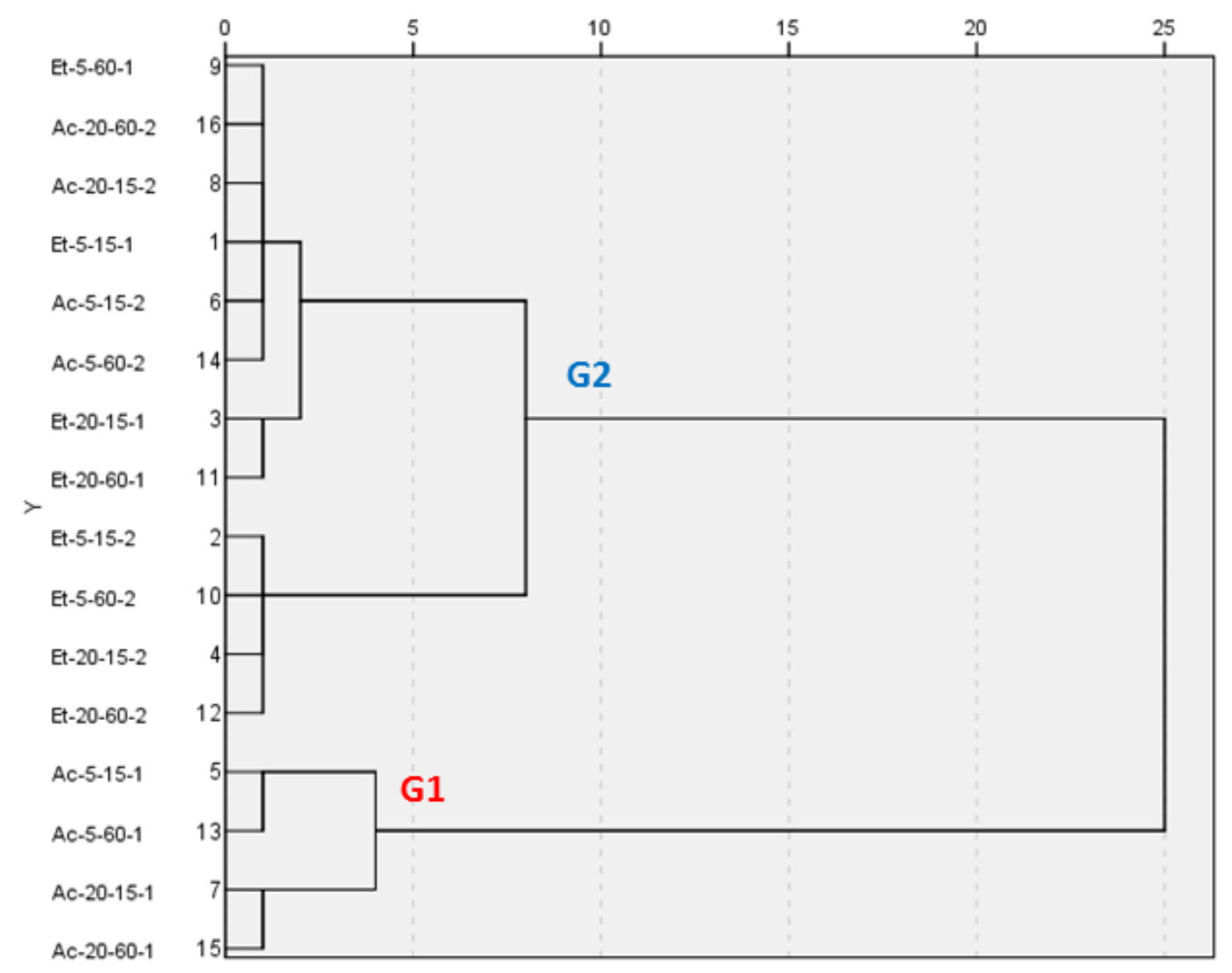

Figure 5. Dendogram using Ward linkage of the different samples analyzed as to total phenolic, anthocyanins and antioxidant activity.

The dendogram clearly evidences two major groups (G1 and G2). The first group includes the first extracts obtained with acetone:water, regardless of the VMR ( 5 or 20 ) and extraction time (15 or $60 \mathrm{~min}$ ). The second group includes all other samples. The samples that fell into group 1 were those in which the AOA quantified was clearly much higher when compared to the other samples, even though not always corresponding to the highest values of TPC or ANT. This is in accordance with the previous results showing AOA as the variable with the highest load for principal components.

\section{Conclusions}

The increasing demand to bioactive compounds from plant extracts encourages continuous search for convenient extractions methods. Strawberries were proved to be rich in antioxidant phenolic compounds, which can be recovered through a solid-liquid extraction process. Both solvents were efficient to extract antioxidant phenolic compounds, particularly when a VMR of $20 \mathrm{~mL} / \mathrm{g}$, for 60 minutes was used. Furthermore, for these extraction conditions, the antioxidant activity was also high. The acetone/water solvent was the most efficient one to extract anthocyanins, and most especially in the first extraction step.

In conclusion, factor analysis showed a grouping structure composed of two components, which was confirmed by the dendogram obtained from cluster analysis. 


\section{Acknowledgements}

This work was financed by FCT - Fundação para a Ciência e Tecnologia, I.P., project UID/Multi/04016/2016. Furthermore, we would like to thank the Instituto Politécnico de Viseu and CI\&DETS for their support through project CI\&DETS/2015/0004.

\section{References}

Aaby, K., Mazur, S., Nes, A., \& Skrede, G. (2012). Phenolic compounds in strawberry (Fragaria x ananassa Duch.) fruits: composition in 27 cultivars and changes during ripening. Food Chemistry, 132(1), 86-97. PMid:26434267. http://dx.doi.org/10.1016/j.foodchem.2011.10.037

Alcântara, M. A., Polari, I. L. B., Meireles, B. R. L. A., Lima Junior, A. E. A., Vieira, J. C. S., Santos, E. A., \& Cordeiro, A. M. T. M. (2019). Effect of the solvent composition on the profile of phenolic compounds extracted from chia seeds. Food Chemistry, 275, 489-496. PMid:30724224. http://dx.doi.org/10.1016/j.foodchem.2018.09.133

Álvarez-Fernández, M. A., Hornedo-Ortega, R., Cerezo, A. B., Troncoso, A. M., \& García-Parrilla, M. C. (2014). Effects of the strawberry (Fragaria ananassa) purée elaboration process on non-anthocyanin phenolic composition and antioxidant activity. Food Chemistry, 164, 104-112. PMid:24996312. http://dx.doi.org/10.1016/j.foodchem.2014.04.116

Andrade, S. C., Guiné, R. P. F., \& Gonçalves, F. J. A. (2017). Evaluation of phenolic compounds, antioxidant activity and bioaccessibility in white crowberry (Corema album). Journal of Food Measurement and Characterization, 11(4), 1936-1946. http://dx.doi.org/10.1007/s11694-017-9576-4

Arend, G. D., Adorno, W. T., Rezzadori, K., Di Luccio, M., Chaves, V. C., Reginatto, F. H., \& Petrus, J. C. C. (2017).

Concentration of phenolic compounds from strawberry (Fragaria $X$ ananassa Duch) juice by nanofiltration membrane. Journal of Food Engineering, 201, 36-41. http://dx.doi.org/10.1016/j.jfoodeng.2017.01.014

Azmir, J., Zaidul, I. S. M., Rahman, M. M., Sharif, K. M., Mohamed, A., Sahena, F., Jahurul, M. H. A., Ghafoor, K., Norulaini, N. A. N., \& Omar, A. K. M. (2013). Techniques for extraction of bioactive compounds from plant materials: A review. Journal of Food Engineering, 117(4), 426-436. http://dx.doi.org/10.1016/j.jfoodeng.2013.01.014

Ballesteros, L. F., Teixeira, J. A., \& Mussatto, S. I. (2014). Selection of the solvent and extraction conditions for maximum recovery of antioxidant phenolic compounds from coffee Silverskin. Food and Bioprocess Technology, 7(5), 1322-1332. http://dx.doi.org/10.1007/s11947-013-1115-7

Bose, S. K., Howlader, P., Jia, X., Wang, W., \& Yin, H. (2019). Alginate oligosaccharide postharvest treatment preserve fruit quality and increase storage life via Abscisic acid signaling in strawberry. Food Chemistry, 283, 665-674. PMid:30722925 http://dx.doi.org/10.1016/j.foodchem.2019.01.060

Broen, M. P. G., Moonen, A. J. H., Kuijf, M. L., Dujardin, K., Marsh, L., Richard, I. H., Starkstein, S. E., Martinez-Martin, P., \& Leentjens, A. F. G. (2015). Factor analysis of the Hamilton depression rating scale in Parkinson's disease. Parkinsonism \& Related Disorders, 21(2), 142-146. PMid:25523963. http://dx.doi.org/10.1016/j.parkreldis.2014.11.016

Chanioti, S., \& Tzia, C. (2018). Extraction of phenolic compounds from olive pomace by using natural deep eutectic solvents and innovative extraction techniques. Innovative Food Science \& Emerging Technologies, 48, 228-239. http://dx.doi.org/10.1016/j.ifset.2018.07.001

Chirinos, R., Rogez, H., Campos, D., Pedreschi, R., \& Larondelle, Y. (2007). Optimization of extraction conditions of antioxidant phenolic compounds from mashua (Tropaeolum tuberosum Ruíz \& Pavón) tubers. Separation and Purification Technology, 55(2), 217-225. http://dx.doi.org/10.1016/j.seppur.2006.12.005

Craft, B. D., Kerrihard, A. L., Amarowicz, R., \& Pegg, R. B. (2012). Phenol-based antioxidants and the In Vitro methods used for their assessment. Comprehensive Reviews in Food Science and Food Safety, 11(2), 148-173. http://dx.doi.org/10.1111/j.15414337.2011.00173.x

Dent, M., Dragović-Uzelac, V., Penić, M., Brnčić, M., Bosiljkov, T., \& Levaj, B. (2013). The effect of extraction solvents, temperature and time on the composition and mass fraction of polyphenols in dalmatian wild sage (Salvia officinalis L.) extracts Food Technology and Biotechnology, 51, 84-91.

Ferreira, I. C. F. R., Martins, N., \& Barros, L. (2017). Phenolic compounds and its bioavailability: In vitro bioactive compounds or health promoters? In F. Toldrá (Ed.), Advances in food and nutrition research (Vol. 82, pp. 1-44). USA: Elsevier Inc. PMid:28427530. http://dx.doi.org/10.1016/bs.afnr.2016.12.004

Gonçalves, F. J., Rocha, S. M., \& Coimbra, M. A. (2012). Study of the retention capacity of anthocyanins by wine polymeric material. Food Chemistry, 134(2), 957-963. PMid:23107713. http://dx.doi.org/10.1016/j.foodchem.2012.02.214

Guerrero-Chavez, G., Scampicchio, M., \& Andreotti, C. (2015). Influence of the site altitude on strawberry phenolic composition and quality. Scientia Horticulturae, 192, 21-28. http://dx.doi.org/10.1016/j.scienta.2015.05.017

Guiné, R. P. F., Almeida, I. C., Correia, A. C., \& Gonçalves, F. J. (2015a). Evaluation of the physical, chemical and sensory properties of raisins produced from grapes of the cultivar Crimson. Journal of Food Measurement and Characterization, 9(3), 337-346. http://dx.doi.org/10.1007/s11694-015-9241-8

Guiné, R. P. F., Barroca, M. J., Gonçalves, F. J., Alves, M., Oliveira, S., \& Correia, P. M. R. (2015b). Effect of drying on total phenolic compounds, antioxidant activity and kinetics decay in pears. International Journal of Fruit Science, 15(2), 173-186. http://dx.doi.org/10.1080/15538362.2015.1017073 
Guiné, R. P. F., Correia, P. M. R., Correia, A. C., Gonçalves, F., Brito, M. F. S., \& Ribeiro, J. R. P. (2018a). Effect of drying temperature on the physical-chemical and sensorial properties of eggplant (Solanum melongena L.). Current Nutrition and Food Science, 14(1), 28-39. http://dx.doi.org/10.2174/1573401313666170316113359

Guiné, R. P. F., Gonçalves, C., Matos, S., Gonçalves, F., Costa, D. V. T. A., \& Mendes, M. (2018b). Modelling through artificial neural networks of the phenolic compounds and antioxidant activity of blueberries. Iranian Journal of Chemistry and Chemical Engineering, 37, 193-212.

Guiné, R. P. F., Gonçalves, F., Lerat, C., Idrisi, T. E., Rodrigo, E., Correia, P. M. R., \& Gonçalves, J. C. (2018c). Extraction of phenolic compounds with antioxidant activity from beetroot (Beta vulgaris L.). Current Nutrition and Food Science, 14(4), 350357. http://dx.doi.org/10.2174/1573401313666170609102336

Guiné, R. P. F., Florença, S. G., Ferrão, A. C., \& Correia, P. M. R. (2019). Investigation about the consumption of edible flowers in Portugal. Indian Journal of Traditional Knowledge, 18, 579-588.

Guiné, R. P. F., Soutinho, S. M. A., \& Gonçalves, F. J. (2014). Phenolic compounds and antioxidant activity in red fruits produced in organic farming. Croatian Journal of Food Science and Technology, 6, 15-2.

Kaiser, H. F., \& Rice, J. (1974). Little Jiffy, Mark Iv. Educational and Psychological Measurement, 34(1), 111-117. http://dx.doi.org/10.1177/001316447403400115

Kajdžanoska, M., Petreska, J., \& Stefova, M. (2011). Comparison of different extraction solvent mixtures for characterization of phenolic compounds in strawberries. Journal of Agricultural and Food Chemistry, 59(10), 5272-5278. PMid:21495681. http://dx.doi.org/10.1021/jf2007826

Lapornik, B., Prošek, M., Wondra, A. G. (2005). Comparison of extracts prepared from plant by-products using different solvents and extraction time. Journal of Food Engineering, 71(2), 214-222. https://doi.org/10.1016/j.jfoodeng.2004.10.036

Manousi, N., Sarakatsianos, I., \& Samanidou, V. (2019). Extraction techniques of phenolic compounds and other bioactive compounds from medicinal and aromatic plants. In A. M. Grumezescu \& A. M. Holban (Ed.), Engineering tools in the beverage industry (Chap. 10, Vol. 3 - The Science of Beverages, pp. 283-314). Sawston: Woodhead Publishing. http://dx.doi.org/10.1016/B978-0-12-815258-4.00010-X.

Maraei, R. W., \& Elsawy, K. M. (2017). Chemical quality and nutrient composition of strawberry fruits treated by y-irradiation. Journal of Radiation Research and Applied Sciences, 10(1), 80-87. http://dx.doi.org/10.1016/j.jrras.2016.12.004

Mazzoni, L., Alvarez Suarez, J. M., Giampieri, F., Gasparrini, M., Forbes Hernandez, T. Y., \& Mezzetti, B. (2017). Evaluation of strawberry (Fragaria $x$ ananassa Duch.) Alba sensorial and nutritional quality, and its in vitro effects against human breast cancer cells viability. Acta Horticulturae, (1156), 379-388. http://dx.doi.org/10.17660/ActaHortic.2017.1156.57

Méndez-Lagunas, L., Rodríguez-Ramírez, J., Cruz-Gracida, M., Sandoval-Torres, S., \& Barriada-Bernal, G. (2017). Convective drying kinetics of strawberry (Fragaria ananassa): effects on antioxidant activity, anthocyanins and total phenolic content. Food Chemistry, 230, 174-181. PMid:28407898. http://dx.doi.org/10.1016/j.foodchem.2017.03.010

Mokrani, A., \& Madani, K. (2016). Effect of solvent, time and temperature on the extraction of phenolic compounds and antioxidant capacity of peach (Prunus persica L.) fruit. Separation and Purification Technology, 162, 68-76. http://dx.doi.org/10.1016/j.seppur.2016.01.043

Morales-Quintana, L., \& Ramos, P. (2019). Chilean strawberry (Fragaria chiloensis): an integrative and comprehensive review. Food Research International, 119, 769-776. PMid:30884715. http://dx.doi.org/10.1016/j.foodres.2018.10.059

Mussatto, S. I., Ballesteros, L. F., Martins, S., \& Teixeira, J. A. (2011). Extraction of antioxidant phenolic compounds from spent coffee grounds. Separation and Purification Technology, 83, 173-179. http://dx.doi.org/10.1016/j.seppur.2011.09.036

Naczk, M., \& Shahidi, F. (2004). Extraction and analysis of phenolics in food. Journal of Chromatography A, 1054(1-2), 95-111. https://doi.org/10.1016/j.chroma.2004.08.059.

Oszmiański, J., \& Wojdyło, A. (2009). Comparative study of phenolic content and antioxidant activity of strawberry puree, clear, and cloudy juices. European Food Research and Technology, 228(4), 623-631. http://dx.doi.org/10.1007/s00217-008-0971-2

Rasera, G. B., Hilkner, M. H., Alencar, S. M., \& Castro, R. J. S. (2019). Biologically active compounds from white and black mustard grains: an optimization study for recovery and identification of phenolic antioxidants. Industrial Crops and Products, 135, 294-300. http://dx.doi.org/10.1016/j.indcrop.2019.04.059

Rodríguez-Gutiérrez, G., Cardoso, J. C., Rubio-Senent, F., Serrano, A., Borja, R., Fernández-Bolaños, J., \& Fermoso, F. G. (2019). Thermally-treated strawberry extrudate: A rich source of antioxidant phenols and sugars. Innovative Food Science \& Emerging Technologies, 51, 186-193. http://dx.doi.org/10.1016/j.ifset.2018.05.017

Santos, S. C. R. V. L., Guiné, R. P. F., \& Barros, A. (2014). Effect of drying temperatures on the phenolic composition and antioxidant activity of pears of Rocha variety (Pyrus communis L.). Journal of Food Measurement and Characterization, 8(2), 105-112. http://dx.doi.org/10.1007/s11694-014-9170-y

Shin, Y., Ryu, J.-A., Liu, R. H., Nock, J. F., \& Watkins, C. B. (2008). Harvest maturity, storage temperature and relative humidity affect fruit quality, antioxidant contents and activity, and inhibition of cell proliferation of strawberry fruit. Postharvest Biology and Technology, 49(2), 201-209. http://dx.doi.org/10.1016/j.postharvbio.2008.02.008

Silva, M. F., Casazza, A. A., Ferrari, P. F., Aliakbarian, B., Converti, A., Bezerra, R. P., Porto, A. L. F., \& Perego, P. (2017). Recovery of phenolic compounds of food concern from Arthrospira platensis by green extraction techniques. Algal Research, 25, 391-401. http://dx.doi.org/10.1016/j.algal.2017.05.027

Stratil, P., Klejdus, B., \& Kubáň, V. (2007). Determination of phenolic compounds and their antioxidant activity in fruits and cereals. Talanta, 71(4), 1741-1751. PMid:19071517. http://dx.doi.org/10.1016/j.talanta.2006.08.012 
Stürtz, M., Cerezo, A. B., Cantos-Villar, E., \& Garcia-Parrilla, M. C. (2011). Determination of the melatonin content of different varieties of tomatoes (Lycopersicon esculentum) and strawberries (Fragaria ananassa). Food Chemistry, 127(3), 1329-1334. PMid:25214134. http://dx.doi.org/10.1016/j.foodchem.2011.01.093

Tulipani, S., Marzban, G., Herndl, A., Laimer, M., Mezzetti, B., \& Battino, M. (2011). Influence of environmental and genetic factors on health-related compounds in strawberry. Food Chemistry, 124(3), 906-913. http://dx.doi.org/10.1016/j.foodchem.2010.07.018

Yang, D., Xie, H., Jiang, Y., \& Wei, X. (2016). Phenolics from strawberry cv. Falandi and their antioxidant and a-glucosidase inhibitory activities. Food Chemistry, 194, 857-863. PMid:26471628. http://dx.doi.org/10.1016/j.foodchem.2015.08.091

Yildiz, H., Ercisli, S., Hegedus, A., Akbulut, M., Topdas, E. F., \& Aliman, J. (2014). Bioactive content and antioxidant characteristics of wild (Fragaria vesca L.) and cultivated strawberry (Fragaria $\times$ ananassa Duch.) fruits from Turkey. Journal of Applied Botany and Food Quality, 87, 274-278.

Zhang, K., Yang, J., Qiao, Z., Cao, X., Luo, Q., Zhao, J., Wang, F., \& Zhang, W. (2019b). Assessment of $\beta$-glucans, phenols, flavor and volatile profiles of hulless barley wine originating from highland areas of China. Food Chemistry, 293, 32-40. PMid:31151618. http://dx.doi.org/10.1016/j.foodchem.2019.04.053

Zhang, M.M., Wang, Z.H., Mao, Y.F., Hu, Y.L., Yang, L., Wang, Y.Y., Zhan, L.L., \& Shen, X. (2019a). Effects of quince pollen pollination on fruit qualities and phenolic substance contents of apples. Scientia Horticulturae, 256, 108628 https://doi.org/10.1016/j.scienta.2019.108628.

Funding: Ministério da Educação e Ciência/Fundação para a Ciência e a Tecnologia UID/Multi/04016/2016. Instituto Politécnico de Viseu and CI\&DETS (project CI\&DETS/2015/0004). 